\title{
A review of Holocene rainforest ecotonal dynamics at opposite ends of the Amazon - Bolivia versus Colombia
}

\author{
Francis E. Mayle, Edinburgh
}

\section{Introduction}

The fate of Amazonia's tropical evergreen rainforests over the $21^{\text {st }}$ century, under different climate change scenarios, is a topic of widespread scientific debate and global concern (BETTs et al. 2008). Most climate models simulate increased drought and reduced available moisture for Amazonia over this century, but the magnitude of drought, and the ability of the rainforest biome to withstand and accommodate such drought, is uncertain (MALHI et al. 2008). One might predict that evergreen rainforest species would be most susceptible to increased drought at ecotones (Fig. 1) towards the highly seasonal margins of the Amazon basin, where they are under greatest moisture stress. An understanding of the response of rainforest ecotones to past climate change may help inform understanding of their likely response to different climate change scenarios for the future. Given the vast geographic area encompassed by Amazonia's rainforest biome, stretching from $\sim 3^{\circ} \mathrm{N}$ to $14^{\circ} \mathrm{S}$, and across the breadth of the South American continent, one would not expect that the magnitude, or even direction, of climate change would be uniform across the basin, especially with respect to the seasonal distribution of rainfall. It is therefore unlikely that the spatio-temporal pattern of ecotonal rainforest dynamics in one part of Amazonia will be representative of ecotones across the basin as a whole.

In this review paper, the aim is to compare and contrast fossil pollen evidence for Holocene rainforest ecotonal dynamics at opposite ends of the Amazon basin - the southern ecotone in NE lowland Bolivia versus the northern ecotone in lowland Colombia. During the Holocene, tropical South America experienced major changes in precipitation (SILva DiAs et al. 2009). Consideration of Amazonian rainforest dynamics over this time-frame may therefore provide important insights into rainforest responsiveness to climate change.

\section{Holocene climate change in Amazonia}

Amazonian rainforest spans the Northern Hemisphere $(\mathrm{NH})$ and Southern Hemisphere $(\mathrm{SH})$ tropics of South America (Fig. 2). Precipitation at the northern and southern rainforest ecotones is highly seasonal, reflecting the insolation-driven seasonal migra- tion of the Intertropical Convergence Zone (ITCZ) and South American Summer Monsoon (SASM). Consequently, the rainy season occurs between October and April (austral summer) at Amazonia's southern rainforest ecotone $\left(\sim 14^{\circ} \mathrm{S}\right)$, but between June and October (NH summer) at its northern rainforest ecotone $\left(\sim 3^{\circ} \mathrm{N}\right)$, reflecting the inter-hemispheric migration of the SASM. Monsoonal precipitation is brought to the southern rainforest ecotone in lowland eastern Bolivia via the South American Low Level Jet (SALLJ) (BERRI \& INZUNZA 1993).

High resolution, direct evidence of Holocene climate change in Amazonia is lacking from sites within the lowland basin, but is available from a number of lakelevel records in the adjacent high Andes. These high altitude sites receive most of their precipitation from the lowlands to the east (Nobre \& SHUKLA 1996), in which case their Holocene palaeoclimate records should also be representative of lowland Amazonia, at least in the western part of the basin. A variety of proxy data from numerous high Andean sites suggest that lowland western Amazonia became significantly drier than present during the early-mid Holocene $(\sim 8,000$ - 4,000 calendar years before present $(8-4$ kyr BP)). The strongest evidence comes from diatom, geochemical and seismic evidence for lake-level low-stands, in particular at Lake Titicaca (e.g., BAKER et al. 2001) (Fig. 2), where lakelevel dropped to $100 \mathrm{~m}$ below present $\sim 6-5 \mathrm{kyr}$ BP.

A clear spatial-temporal trend is evident, whereby lake-level low-stands in the SH tropical Andes occur progressively later in the Holocene with increasing latitude (Аввотт et al. 2003; Bush et al. 2005). Precipitation minima occur at $10 \mathrm{kyr}$ BP at Lake Junin $\left(11^{\circ} \mathrm{S}\right)$, $5.5 \mathrm{kyr} \mathrm{BP}$ at Lake Titicaca $\left(14-17^{\circ} \mathrm{S}\right)$, and $4 \mathrm{kyr} \mathrm{BP}$ at Sajama Mountain $\left(18^{\circ} \mathrm{S}\right)$. This trend is consistent with the $20 \mathrm{kyr}$ precession orbital cycle (BERGER 1992) as the ultimate driver of long-term (multi-millennial scale) climate change through the Holocene, whereby a gradual increase in austral $(\mathrm{SH})$ summer insolation increases the strength of the SASM (ZHOU \& LAU 1998) which extends increasingly southward in the SH tropics.

\section{Rainforest ecotonal dynamics in southern Amazonia}

Lagunas Bella Vista, Chaplin, and Yaguarú are lakes located in the lowlands of NE Bolivia at the ecotone between Amazonian humid evergreen rainforests to 


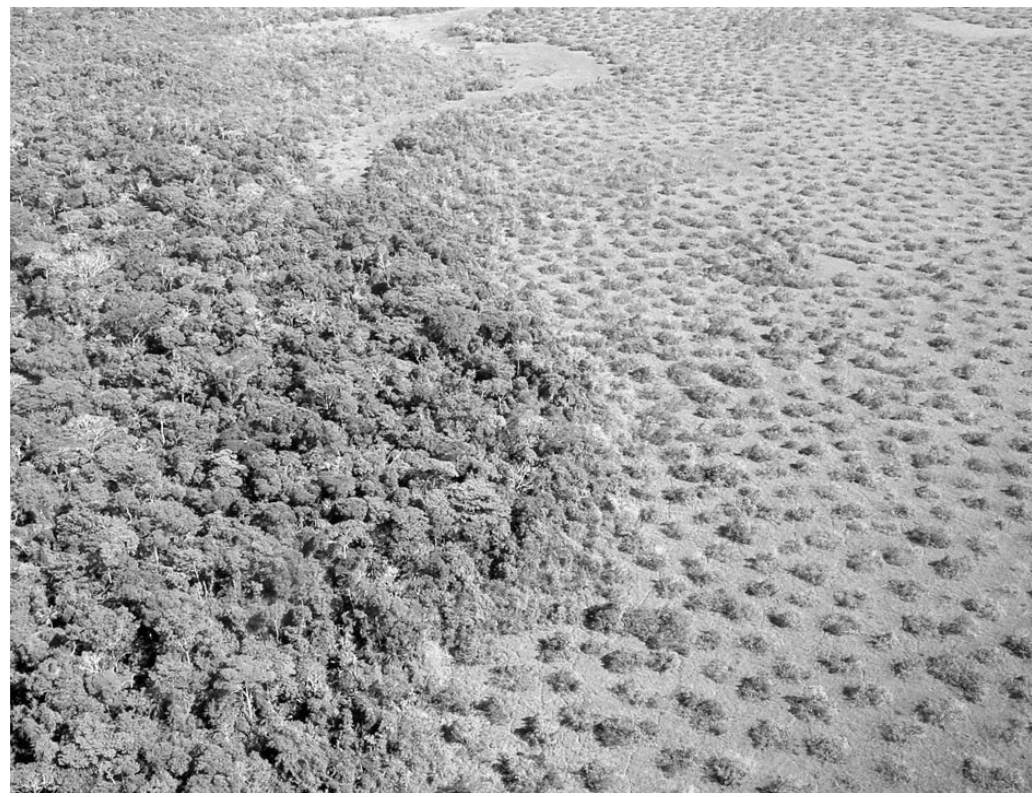

Fig. 1: Ecotone between humid evergreen rainforest and seasonally-flooded termite savanna in Noel Kempff Mercado National Park, NE Bolivia

Ökoton zwischen humidem immergrünem Regenwald und saisonal überfluteter Termitensavanne im Noel Kempff Mercado Nationalpark, Nordost-Bolivien

Zone de transition écologique entre la forêt sempervirente et la savane périodiquement inondée à termitières du Parc national Noel Kempff Mercado, nord-est de la Bolivie

Photo:T.J. KILLEEN, 2007

the north and the Chiquitano seasonally dry semideciduous tropical forest (SDTF) to the south (Fig. 2). Interspersed among the SDTF are patches of upland (cerrado) savanna, which dominate further east in the Cerrado savanna biome of Brazil.

\subsection{Lagunas Chaplin and Bella Vista}

Lagunas Chaplin $(\mathrm{CH})\left(14^{\circ} 28^{\prime} \mathrm{S}, 61^{\circ} 04^{\prime} \mathrm{W}\right)$ and Bella Vista (BV) $\left(13^{\circ} 37^{\prime} \mathrm{S}, 61^{\circ} 33^{\prime} \mathrm{W}\right)$ are large, shallow, flatbottomed lakes that lie within Noel Kempff Mercado National Park (NKMNP) of NE Bolivia, a 15,000 km² protected area that borders Mato Grosso and Rondonia states of Brazil. They are both surrounded by tall humid evergreen rainforest and are located $30 \mathrm{~km}$ and $130 \mathrm{~km}$, respectively, north of the ecotone with the Bolivian Chiquitano Dry Forest. Mean annual precipitation at $\mathrm{CH}$ and $\mathrm{BV}$ is $1500 \mathrm{~mm}$ and $1600 \mathrm{~mm}$, respectively (World Meteorological Organisation \& Hoffmann 1975). Mayle et al. (2000) and BurBRIDGE et al. (2004) showed that, through the early-mid Holocene, the catchment of both sites was dominated by seasonally-flooded savannas (referred to locally as «pampa») in the immediate vicinity of the lakes and around the floodplains of the neighbouring rivers and streams. Evidence for this comes from pollen assemblages dominated by Cyperaceae, Poaceae, Mauritial Mauritiella, and Curatella americana. That the landscape was open at this time is corroborated by minimal pollen percentages of the wind-pollinated Moraceae family $(<10 \%)$, which dominates rainforest communities in the region today (GosLiNG et al. 2005). Well drained (terra firme) areas around both lakes were covered by a mosaic of upland (cerrado) savannas (e.g., Curatella americana) and SDTF (Anadenanthera, Astronium, Gallesia).

This mosaic of savanna and SDTF in the catchments of both $\mathrm{CH}$ and $\mathrm{BV}$ in the early-mid Holocene (until $\sim 6.8-3.2 \mathrm{kyr} \mathrm{BP}$ ) is coincident with lower-thanpresent lake levels at Lake Titicaca (which lies at a similar latitude on the Altiplano of the Andes to the west), providing strong evidence that these vegetation communities reflect lower mean annual precipitation $(<1500 \mathrm{~mm})$ and a longer dry season $(>5$ 


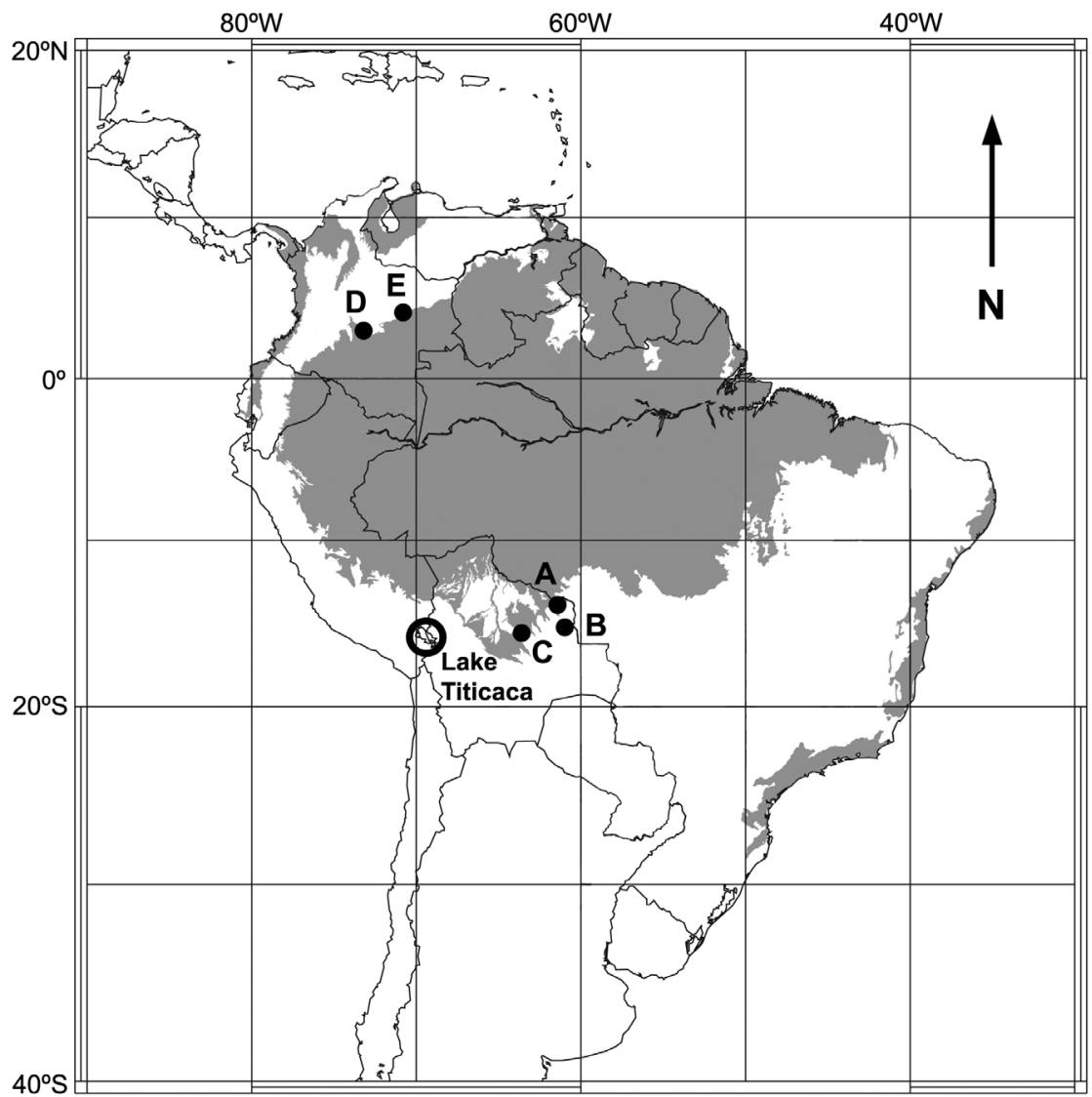

Fig. 2: Biome map of humid evergreen rainforest (following OLSON et al. 2001), showing locations of study sites discussed in the text in relation to Amazonia's northern and southern rainforest ecotones. A: Laguna Bella Vista (Burbridge et al. 2004), B: Laguna Chaplin (Burbridge et al. 2004), C: Laguna Yaguarú (TAYLOR et al. 2010), D: Laguna Loma Linda (BeHLing \& Hooghiemstra 2000), E: Laguna Chenevo (BerRio et al. 2002)

Verbreitung des humiden immergrünen Regenwaldes (nach OLSON et al. 2001) mit Lage der im Text diskutierten Profile in den nördlichen und südlichen Ökotonen des Amzonas-Regenwaldes.

Carte du biome de la forêt sempervirente (d'après OLson et al. 2001), montrant la localisation des zones d'étude discutées dans le texte en relation avec les zones de transitions écologiques de forêts tropicales du nord et du sud de l'Amazonie.

months with $<100 \mathrm{~mm}$ ) than today. The gradual rise in Moraceae pollen percentages, beginning between 6.8 and $3.2 \mathrm{kyr} \mathrm{BP}$ at $\mathrm{BV}$ and $\sim 2.8 \mathrm{kyr} \mathrm{BP}$ at $\mathrm{CH}$, coinciding with a decline in relative abundance of savanna and SDTF taxa, reflects an expansion of humid evergreen rainforest communities into NKMNP (BURBRIDGE et al. 2004; BURN et al. 2010). The timing of this trend correlates with rising lake-levels at Lake Titicaca, demonstrating that this expansion of humid evergreen rainforest was likely driven by increasing precipitation. The catchments of these lakes were dominated by tall, closed-canopy rainforest by 2 kyr $\mathrm{BP}$ at $\mathrm{BV}$ and $0.65 \mathrm{kyr} \mathrm{BP}$ at $\mathrm{CH}$, when pollen assemblages were similar to present. Recent modern pollen rain studies (BURN et al. 2010) and advances in Moraceae pollen taxonomy (BURN \& MAYLE 2008) reveal that this late Holocene ecotonal shift involved expansions in geographic extent of both riparian, seasonally-flooded, and terra firme upland, humid evergreen rainforest. That these late Holocene changes in palynological assemblages signify vegetation responses to increased precipitation is further supported by application of a climate-vegetation model (PunYasena 2008), based on the modern abundance 
distributions of 154 Neotropical rainforest families, to the $\mathrm{CH}$ pollen dataset. This model, employing family-level analysis, suggests that the savanna/dry forest pollen assemblages signify early-mid Holocene mean annual precipitation $\sim 300-400 \mathrm{~mm} / \mathrm{yr}$ below present (Punyasena et al. 2008).

\subsection{Laguna Yaguarú}

Laguna Yaguarú $\left(15^{\circ} 36^{\prime} \mathrm{S}, 63^{\circ} 13^{\prime} \mathrm{W}\right)$ is a sinuous lake of fluvial origin, located $\sim 250 \mathrm{~km} \mathrm{WSW}$ of Laguna Chaplin, also at the ecotone between humid evergreen rainforest to the north and semi-deciduous Chiquitano dry forest to the south. Mean annual precipitation at this site is $\sim 1200 \mathrm{~mm}$ (World Meteorological Organisation \& Hoffmann 1975). However, in contrast to $\mathrm{BV}$ and $\mathrm{CH}$, this site is located on the dry forest, rather than rainforest, side of the ecotone. The fossil pollen record from this lake (TAYLOR et al. 2010) shows that SDTF surrounded this site since at least 5.3 kyr BP, the principal evidence coming from abundance of the dry forest indicator Anadenanthera. However, a combination of increasing Celtis pollen percentages, more negative $\delta^{13} \mathrm{C}$ values, and a reduction in charcoal, together point to increasing forest density/ cover and increasing precipitation since $\sim 1.2 \mathrm{kyr}$ BP. Therefore, although the forest compositional changes are quite different between Yaguarú and the two sites in Noel Kempff Mercado National Park, the pattern of ecotonal changes at all three sites signify vegetation responses to progressively increasing precipitation through the late Holocene.

There is a clear trend of progressively later forest expansions with increasing latitude across this rainforest-dry forest ecotone - between $6.8-3.2 \mathrm{kyr} \mathrm{BP}$ at BV (13 $\left.37^{\circ} \mathrm{S}\right), \sim 2.8 \mathrm{kyr} \mathrm{BP}$ at $\mathrm{CH}\left(14^{\circ} 28^{\prime} \mathrm{S}\right)$, and 1.2 kyr BP at Yaguarú $\left(15^{\circ} 36^{\prime} \mathrm{S}\right)$. However, it is not clear whether this spatio-temporal trend reflects the timetransgressive increase in precipitation reported from sites in the tropical Andes, or instead delayed vegetation responses governed by rates of tree population spread and competitive replacement.

\section{Rainforest ecotonal dynamics in northern Amazonia}

Lagunas Loma Linda and Chenevo are lakes of fluvial origin, $\sim 300 \mathrm{~km}$ apart, located at Amazonia's northern rainforest ecotone, between humid evergreen Amazonian rainforest to the south and seasonally-flooded savannas of the Colombian «Llanos Orientales» to the north (Fig. 2). Both sites are located on the savanna side of the ecotone and are surrounded by stands of Mauritia palm. Mean annual precipitation at these two sites is $2800 \mathrm{~mm}$ (Loma Linda) and $1900 \mathrm{~mm}$ (Chenevo) (World Meteorological Organisation \& HOFFMANN 1975).

\subsection{Laguna Loma Linda}

Laguna Loma Linda (LL) $\left(3^{\circ} 18^{\prime} \mathrm{N}, 73^{\circ} 23^{\prime} \mathrm{W}\right)$, located in the western Llanos Orientales, yielded a $~ 9.6 \mathrm{kyr}$ Holocene fossil pollen record (Behling \& HooghiemSTRA 2000), which shows a broadly similar pattern of ecotonal dynamics to that of lowland Bolivia at the opposite end of the basin. Between $~ 9.6$ and 6.9 kyr BP the lake catchment was dominated by herbaceous savanna, which was more open, and extended $\sim 100 \mathrm{~km}$ further south than today's savanna, reflecting drier than present conditions. Since then, a twostep rainforest expansion occurred. There was a substantial expansion in gallery forest at $6.9 \mathrm{kyr} \mathrm{BP}$, evident from several-fold increases in pollen percentages of Moraceae/Urticaceae, Alchornea, and Cecropia, followed by a further gallery forest expansion at $\sim 3.9 \mathrm{kyr}$ BP. This pattern is suggestive of an ecotonal response to a step-wise increase in precipitation. A re-expansion of savanna and Mauritia palm occurred over the past $2.3 \mathrm{kyr}$, although BeHLing \& HooghiemSTRA (2000) attribute this to human impact (forest clearance) rather than any decrease in rainfall.

\subsection{Laguna Chenevo}

Laguna Chenevo (CV) $\left(4^{\circ} 05^{\prime} \mathrm{N}, 70^{\circ} 21^{\prime} \mathrm{W}\right)$, located in the eastern Llanos Orientales, has a fossil pollen record that shows a broadly similar trend of midHolocene ecotonal forest expansion to LL, albeit involving different tree taxa (Mauritia rather than Moraceae) and with a gradual, rather than step-wise, forest increase (BERRIO et al. 2002). Between 8 and 7 kyr BP the surrounding landscape was dominated by open herbaceous savanna, as at LL. Forest and gallery forest then expanded continuously between $\sim 7$ and 4.5 kyr BP, predominantly driven by Mauritia, after which the ecotone appears to have been largely stable until present, although compositional changes to the forest occurred 2.4 kyr BP (e.g., expansion of Virola and Mauritiella and disappearance of Myrtaceae).

\section{Synthesis}

These fossil pollen records show that rainforests expanded their range through the Holocene in ecotonal regions of both the southern $(\mathrm{SH})$ and northern hemispheres $(\mathrm{NH})$ of Amazonia, although rainforest expansion began somewhat earlier in the $\mathrm{NH}$ (Colombia) than the SH (Bolivia). The mid-late Holocene rainforest expansion in Bolivia broadly matches the trend of Andean lake-level rise in the SH tropics, both of which are best explained by increasing strength of the SASM and greater southerly migration of the ITCZ. The latter in turn can be attributed to progressively increasing convective heating in the continental interior arising from increasing $\mathrm{SH}$ summer insolation driven by the $\sim 20 \mathrm{kyr}$ precession orbital cycle. 
However, the mid Holocene rainforest expansion at Amazonia's NH ecotone in Colombia is more difficult to explain in terms of orbital forcing. If the precession orbital cycle is the ultimate driver of these long-term Holocene ecotonal dynamics in Amazonia, then one would expect that the direction of ecotonal movement at the NH sites in Colombia would be opposite to that of the SH sites in Bolivia (i.e., progressive contraction, rather than expansion, of gallery forest through the mid-late Holocene as NH summer insolation progressively declines through the Holocene).

Irrespective of the root causes of these ecotonal movements through the Holocene, it is clear that Amazonia's ecotonal rainforests have been responsive to changes in precipitation through the Holocene, and would therefore be expected to respond dynamically to future climate change over the $21^{\text {st }}$ century. «Climate change-integrated conservation strategies» (CCS) (HANnAH et al. 2002) are therefore needed for Amazonia's ecotonal rainforests, that explicitly allow for dynamic ecosystem change, for example via landscape corridors.

\section{Literature}

Аввотt, M.B., Wolfe, B.B., Wolfe, A.P. Seltzer, G.O. Aravena, R., Mark, B.G., Polissar, P.J., Rodbell, D.T., Rowe, H.D. \& M. Vuille (2003): Holocene paleohydrology and glacial history of the central Andes using multiproxy lake sediment studies. - In: Palaeogeography, Palaeoclimatology, Palaeoecology 194: 123-138.

Baker, P.A., Seltzer, G.O., Fritz, S.C., Dunbar, R.B., Grove, M.J., Tapia, P.M., Cross, S.L., Rowe, H.D. \& J.P. BrodA (2001): The history of South American tropical precipitation for the past 25,000 years. - In: Science 291, 5504: 640-643.

Behling, H. \& H. Hooghiemstra (2000): Holocene Amazon rainforest-savanna dynamics and climatic implications: high-resolution pollen record from Laguna Loma Linda in eastern Colombia. - In: Journal of Quaternary Science 15, 7: 687-695.

Berger, A. (1992): Orbital variations and insolation database. - In: IGBP PAGES/World Data Center for Paleoclimatology, Data Contribution Series, vol. 92-007; Boulder, CO: NOAA/NCDC Paleoclimatology Program.

BERRI, G.J. \& J.B. InZUnZa (1993): The effect of the low-level jet on the poleward water vapour transport in the central region of South America. - In: Atmospheric Environment 27A, 3:335-341.

Berrio, J.C., Hooghiemstra, H., Behling, H., Botero, P. \& K. VAN DER BORG (2002): Late-Quaternary savanna history of the Colombian Llanos Orientales from Lagunas Chenevo and Mozambique: a transect synthesis. - In: The Holocene 12, 1: 35-48.

Betts, R.A., Malhi, Y. \& J.T. Roberts (2008): The future of the Amazon: new perspectives from climate, ecosystem and social sciences. - In: Philosophical Transactions of the Royal Society B 363, 1498: 1729-1735.

Burbridge, R.E., Mayle, F.E. \& T.J. Killeen (2004): Fifty thousand-year vegetation and climate history of Noel Kempff Mercado National Park, Bolivian Amazon. - In: Quaternary Research 61: 215-230.

Burn, M.J. \& F.E. Mayle (2008): Palynological differentiation between genera of the Moraceae family and implications for Amazonian palaeoecology. - In: Review of Palaeobotany and Palynology 149: 187-201. Burn, M.J., Mayle, F.E. \& T.J. Killeen (2010): Pollenbased differentiation of Amazonian rainforest communities and implications for lowland palaeoecology in tropical South America. - In: Palaeogeography, Palaeoclimatology, Palaeoecology 295: 1-18.

Bush, M.B., Hansen, B.C.S., Rodbell, D.T., Seltzer, G.O., Young, K.R., Leon, B., Аввотt, M.B., Silman, M.R. \& W.D. GosLING (2005): A 17000-year history of Andean climate and vegetation change from Laguna de Chochos, Peru. - In: Journal of Quaternary Science 20, 7-8: 703-714.

Gosling, W.D., Mayle, F.E., Tate, N.J. \& T.J. Killeen (2005): Modern pollen rain characteristics of tall terra firme moist evergreen forest, southern Amazonia. - In: Quaternary Research 64, 3: 284-297.

Hannah, L., Midgley, G.F., Lovejoy, T., Bond, W.J., Bush, M., LovetT, J.C., Scott, D. \& F.I. Woodward (2002): Conservation of biodiversity in a changing climate. - In: Conservation Biology 16, 1: 264-268.

Malhi, Y., Roberts, J.T., Betts, R.A., Killeen, T.J., LI, W. \& C.A. Nobre (2008): Climate change, deforestation and the fate of the Amazon. - In: Science 319, 5860: 169-172.

Mayle, F.E., Burbridge, R. \& T.J. Killeen (2000): Millennial scale dynamics of southern Amazonian rain forests. - In: Science 290, 5500: 2291-2294.

Nobre, P. \& J. ShukLa (1996): Variations of sea surface temperature, wind stress, and rainfall over the tropical Atlantic and South America. - In: Journal of Climatology 9: 2464-2479.

Olson, D.M., Dinerstein, D., Wikramanayake, E.D., Burgess, N.D. Powell, G.V.N., Underwood, E.C., D'Amico, J.A., Itoua, I., Strand, H.E., Morrison, J.C., Loucks, C.J., Allnutt, T.F., RicketTs, T.H., Kura, Y., Lamoreux, J.F., Wettengel, W.W., Hedao, P. \& K.R. KASSEM (2001): Terrestrial ecoregions of the world: a new map of life on Earth. - In: Bioscience 51, 11: 933938.

Punyasena, S.W. (2008): Estimating neotropical paleotemperature and paleoprecipitation using plant family climatic optima. - In: Palaeogeography, Palaeoclimatology, Palaeoecology 265, 3-4: 226-237.

Punyasena, S.W., Mayle, F.E. \& J.C. McElwain (2008): Quantitative estimates of glacial and Holocene temperature and precipitation change in lowland Amazonian Bolivia. - In: Geology 36, 8: 667-670. 
Silva Dias, P.L., Turce, B., Silva Dias, M.A.F., BraCONNOT, P. \& T. JorgetTI (2009): Mid-Holocene climate of tropical South America: a model-data approach. In: Vimeux, F., Sylvestre, F. \& M. Khodri (eds): Past climate variability in South America and surrounding regions: from the Last Glacial Maximum to the Holocene. - Developments in Paleoenvironmental Research 14, Dordrecht: Springer.

TAYlor, Z.P., Horn, S.P., Mora, C.I., Orvis, K.H. \& L.W. Cooper (2010): A multi-proxy palaeoecological record of late-Holocene forest expansion in lowland Bolivia. - In: Palaeogeography, Palaeoclimatology, Palaeoecology 293, 1-2: 98-107.

World Meteorological Organisation \& J. HoffMANN (1975): Atlas climatico de America del Sur. Ginebra: OMM.

Zhou, J.Y. \& K.M. LaU (1998): Does a monsoon climate exist over South America? - Journal of Climatology 11: 1020-1040.

\section{Summary: A review of Holocene rainforest ecotonal dynamics at opposite ends of the Amazon - Bolivia versus Colombia}

This review paper examines Holocene fossil pollen records from selected lake sites to investigate how rainforests at Amazonia's northern and southern ecotones, of lowland Colombia and Bolivia, respectively, responded to Holocene climate change. Despite their geographic separation in different hemispheres $\left(\sim 3^{\circ} \mathrm{N}\right.$ versus $14^{\circ} \mathrm{S}$ ), both northern and southern ecotonal sites show a surprisingly consistent pattern of rainforest expansion through the Holocene. Orbital forcing, according to the precession cycle, is a likely explanation for this rainforest expansion at the Southern Hemisphere ecotone, via progressively greater austral summer insolation and consequent strengthening of the South American Summer Monsoon, but is inconsistent with rainforest expansion at Amazonia's northern ecotone.

Keywords: ecotone, Amazon, rainforest, pollen, Holocene

\section{Zusammenfassung: Ein Überblick der holozänen Dynamik des Regenwaldökotons an entgegengesetz- ten Enden des Amazonasbeckens - Bolivien versus Kolumbien}

Dieser Überblicksartikel vergleicht holozäne Pollenprofile ausgewählter Seen am Nord- und Südrand des Amazonas-Gebietes in Kolumbien und Boliven, um zu untersuchen, wie die Grenzbereiche der Tiefland-
Regenwälder auf holozäne Klimaschwankungen reagierten. Trotz ihrer geographischen Aufteilung auf beide Hemisphären $\left(\sim 3^{\circ} \mathrm{N}\right.$ gegenüber $\left.14^{\circ} \mathrm{S}\right)$ zeigen beide Ökotone im Norden wie im Süden überraschend übereinstimmende Muster der Regenwaldausbreitung während des Holozäns. Erdbahnparameter, vor allem der Präzessions-Zyklus, könnten die Regenwaldausbreitung am Südrand mit zunehmender Einstrahlung im Sommer und einer dadurch bedingten Stärkung des Südamerikanischen Sommermonsuns erklären. Diese Erklärung greift aber nicht für den Nordrand des Amazonas-Regenwaldes.

Schlüsselwörter: Ökotone, Amazonas, Regenwald, Pollen, Holozän

\section{Résumé: Dynamiques écotonales des forêts tropicales de l'Holocène aux deux extrêmes de l'Amazone - Bolivie versus Colombie}

Cette étude examine des relevés fossiles de pollen récoltés dans certains lacs afin d'analyser comment les forêts tropicales des écotones nord et sud de l'Amazonie (basses terres de Colombie et Bolivie) ont réagi aux changement climatique durant l'Holocène. En dépit de leur appartenance géographique à deux hémisphères différents $\left(\sim 3^{\circ} \mathrm{N}\right.$ versus $\left.14^{\circ} \mathrm{S}\right)$, les deux écotones montrent une surprenante similarité en ce qui concerne l'expansion des forêts tropicales durant l'Holocène. Le forçage orbital, en particulier le cycle de précession, est une explication plausible de cette expansion des forêts tropicales dans l'écotone de l'hémisphère sud, à travers une insolation australe devenue progressivement plus importante et un renforcement consécutif de la mousson estivale sud-américaine, mais demeure contradictoire avec l'expansion des forêts tropicales dans l'écotone nord de l'Amazonie.

Mots-clés: écotone, Amazone, forêt tropicale, pollen, Holocène

Dr. Francis E. Mayle, School of Geosciences, The University of Edinburgh, Drummond Street, Edinburgh EH8 9XP, United Kingdom.

e-mail: francis.mayle@ed.ac.uk

\section{Manuskripteingang/received/manuscrit reçu le}

18.4.2011

Annahme zum Druck/accepted for publication/accepté pour publication: 13.10 .2011 